\title{
Inheritance of the Bantu/Benin haplotype causes less severe hemolytic and oxidative stress in sickle cell anemia patients treated with hydroxycarbamide
}

\author{
Jéssika V Okumura ${ }^{1}$, Danilo GH Silva ${ }^{1}$, Lidiane $S$ Torres $^{1}$, Edis Belini-Junior ${ }^{1}$, Willian M Barberino ${ }^{1}$, \\ Renan G Oliveira ${ }^{1}$, Gisele CS Carrocini ${ }^{1}$, Gabriela B Gelaleti ${ }^{2}$, Clarisse LC Lobo ${ }^{3}$ and \\ Claudia R Bonini-Domingos ${ }^{1}$
}

Beta S-globin gene cluster haplotypes ( $\beta^{\mathrm{S}}$-haplotypes) can modulate the response to hydroxycarbamide $(\mathrm{HC})$ treatment in sickle cell anemia (SCA) patients. In Brazil, the most common haplotypes are Bantu and Benin, and both confer a poor prognosis for patients when untreated with HC. We evaluated oxidative and hemolytic biomarkers in 48 SCA patients undergoing HC treatment separated in three subgroups: Bantu/Bantu, Bantu/Benin and Benin/Benin haplotype. On the basis of reduced haptoglobin (HP) levels, patients with Bantu/Bantu haplotypes had 3.0\% higher hemolysis degree when compared with those with Bantu/Benin haplotypes $(P=0.01)$. The Benin/Benin patients had $53.6 \%$ greater lipid peroxidation index than the Bantu/Bantu patients $(P=0.01)$ because of evaluated thiobarbituric acid reactive species levels. The Bantu/Benin subgroup had intermediate levels of hemolytic and oxidative stress markers compared with the homozygous subgroups. Through strict inclusion criteria adopted, as well as consolidated and well-described hemolytic and the oxidative parameters evaluated, we suggest a haplotype-interaction response to HC treatment mediated by a 'balance' between the genetic factors of each haplotype studied.

Journal of Human Genetics (2016) 61, 605-611; doi:10.1038/jhg.2016.16; published online 10 March 2016

\section{INTRODUCTION}

Sickle cell anemia (SCA) is a genetic disease characterized by homozygous hemoglobin S (Hb SS, HBB:c.20A > T, rs334) which causes two major pathophysiological processes: hemolysis and vaso-occlusion. ${ }^{1,2}$ In SCA, the majority of hemolysis is extravascular, being approximately two-thirds of the total hemolysis, and it is characterized by destruction of the damaged erythrocytes by spleen macrophages. ${ }^{3,4}$ However, intravascular hemolysis, corresponding to one-third of the total hemolysis, is also frequent and occurs by polymerization and depolymerization processes of $\mathrm{Hb} \mathrm{S}$. This process promotes irreversible damage to the erythrocyte membrane, leading to its rupture and further release of $\mathrm{Hb}$ into the plasma. ${ }^{3-5}$ The free plasma $\mathrm{Hb}$ becomes an unstable molecule and dissociates into alphabeta globin dimers, which may release the heme group. ${ }^{6}$ The $\mathrm{Hb}$ and free heme group have their levels increased in the plasma as a result of intravascular hemolysis and both participate in reactions that produce toxicity $^{7,8}$ and oxidative stress. ${ }^{9}$

Oxidative control of free $\mathrm{Hb}$ and its subunits is essential to maintain the integrity of membranes. In the presence of these stressors, endogenous non-enzymatic defense mechanisms, such as plasma glycoproteins, act to minimize toxicity thereby reducing damage. ${ }^{7,8,10}$ The first line of control against the effects of intravascular hemolysis is the depletion of free $\mathrm{Hb}$ by haptoglobin (HP) forming an irreversible complex (HP-Hb), which is removed from circulation by the CD163 protein.,11,12 However, in severe hemolysis, the buffering capacity of plasma $\mathrm{Hp}$ is exceeded and free $\mathrm{Hb}$ is quickly oxidized to methemoglobin, which releases free heme. ${ }^{13}$ The protein hemopexin (HPx) is the main free heme scavenger. ${ }^{7}$ The complex formed (HPx-heme) is removed from circulation by the CD91/LRP receptor. ${ }^{14}$ Owing to chronic hemolysis, SCA patients have decreased HP and HPx plasma levels. ${ }^{415-17}$ In addition to this physiological response to chronic hemolysis, the human erythropoietin (EPO), an acidic glycoprotein, acts on the erythroid lineage, particularly on colonyforming units-erythroid, promoting the survival, proliferation and differentiation of erythroid precursors and thus leading to red cells formation. ${ }^{18-20}$ In beta-hemoglobinopathies, such as SCA and beta-thalassemias, the levels of EPO are high but lower than expected for the degree of anemia. ${ }^{21,22}$

Furthermore, some drugs such as hydroxycarbamide (HC) are used to minimize the effects of the pathophysiological processes triggered by $\mathrm{HbS}$, owing to its multifaceted therapeutic effects. For instance, $\mathrm{HC}$ increases fetal hemoglobin ( $\mathrm{Hb} \mathrm{F}$ ) levels, acts as a nitric oxide donor and reduces the expression of adhesion molecules, thereby contributing to a reduction of vaso-occlusive ${ }^{23,24}$ and hemolytic events. ${ }^{25}$

\footnotetext{
${ }^{1}$ Department of Biology, Hemoglobin and Hematological Genetic Diseases Laboratory, Sao Paulo State University (UNESP), Sao Paulo, Brazil; ${ }^{2}$ Department of Molecular Biology, Sao Jose do Rio Preto Medical School (FAMERP), Sao Paulo, Brazil and ${ }^{3}$ Hematological State Institute 'Arthur de Siqueira Cavalcanti' (HEMORIO), Rio de Janeiro, Brazil Correspondence: JV Okumura, Department of Biology, Hemoglobin and Hematological Genetic Diseases Laboratory, Sao Paulo State University (UNESP), Cristovao Colombo street, n² 2265, Jardim Nazareth, Sao Paulo 15054-000, Brazil.

E-mail: jessika_okumura@hotmail.com

Received 16 December 2015; revised 1 February 2016; accepted 3 February 2016; published online 10 March 2016
} 
However, the response varies greatly between SCA patients and the mechanisms involved have not been fully elucidated. Large genome association studies suggested that genetic modulators, including the haplotypes associated with the beta S-globin gene cluster ( $\beta^{S}$-haplotypes), may be involved in the different responses to HC treatment. ${ }^{26,27}$ There are five typical $\beta^{\text {S}}$-haplotypes that are named according to the region in which they were identified: Benin, Bantu or Central African Republic, Senegal, ${ }^{28}$ Saudi-Arabia India (Saudi) ${ }^{29}$ and Cameroon. ${ }^{30}$ In Brazil, the most common are the Bantu and Benin haplotypes. ${ }^{31-33}$ These haplotypes cause, respectively, severe and moderate clinical symptoms in SCA patients due, in part, to the low $\mathrm{Hb} \mathrm{F}$ levels. ${ }^{34,35}$ Owing to miscegenation in some populations, it is common to find different combinations for the polymorphic sites which determine the $\beta^{S}$-haplotypes. These combinations that do not characterize any one of the five typical haplotypes, previously described, are denominated as atypical haplotypes. ${ }^{28}$

There are reports in the literature of differential responses of Brazilian SCA patients to the HC treatment according to the $\beta^{\mathrm{S}}$ haplotypes, especially in relation to inflammation, oxidative stress, DNA damage and $\mathrm{Hb} \mathrm{F}$ levels. ${ }^{27,36-38}$ However, to the authors' knowledge, this is the first study that explores the differential responses to HC therapy of Brazilian SCA patients with the Bantu and/or Benin haplotypes using EPO, HP and HPx as main hemolytic and oxidative stress biomarkers.

\section{MATERIALS AND METHODS}

\section{Patients}

The study group was selected from 527 SCA patients regularly treated at the Hematology Institute 'Arthur de Siqueira Cavalcanti'-HEMORIO. All patients completed a questionnaire to provide information for studied subgroup composition. The exclusion criteria were: pregnant women, smokers, alcoholics, patients who received blood transfusions in 120 days prior to blood sampling and individuals taking recombinant human EPO and darbepoetin alfa or other drugs (acetylsalicylic acid, antibiotics or vitamins) within $72 \mathrm{~h}$ prior to blood collection. The inclusion criteria were: all the patients had to be older than 5 years of age and present Bantu and/or Benin haplotypes. Furthermore, they were in clinical steady-state and medicated with $\mathrm{HC}$ but not under maximum tolerated dose (mean dose of $22 \mathrm{mg} \mathrm{kg}^{-1}$ per day) for at least six months.

All subjects consented to participate in this study that was approved by the Supervision and Data Security Board of the institution in accordance with the Brazilian norms and Research Ethics Committee.

\section{Blood samples}

Four milliliters of peripheral blood were collected by venipuncture in tubes containing 5\% ethylenediaminetetraacetic acid. An aliquot of $2 \mathrm{ml}$ was centrifuged at 2000 r.p.m. for $20 \mathrm{~min}$ to separate the plasma. The plasma samples were used to measure EPO, HP and HPx plasma levels and assess lipid peroxidation levels. The remaining $2 \mathrm{ml}$ of peripheral blood were submitted to tests to classify the $\mathrm{Hb}$ profile and extract DNA from the leukocytes. ${ }^{39}$

\section{Phenotypes of $\mathrm{Hb}$, genotypes and characterization of beta S-globin gene cluster haplotypes}

Alkaline electrophoresis on cellulose acetate $(\mathrm{pH} 8.6)^{40}$ and electrophoresis at acidic $\mathrm{pH}(\mathrm{pH} 6.2)$ were used to identify the $\mathrm{Hb}$ profile. ${ }^{41}$ Quantification of $\mathrm{Hb} \mathrm{F}$ was obtained by high performance liquid chromatography using automated equipment (VARIANT, Bio-Rad Laboratories, Hercules, CA, USA). The genotype of $\mathrm{Hb} \mathrm{S}$ was confirmed by molecular biology using the polymerase chain reaction-restriction fragment length polymorphism methodology. ${ }^{42}$ The encoding of the mutation for beta S-globin gene $\left(H B B^{*}\right.$ S:c.20A $>\mathrm{T}$ - rs334) was achieved by specific primers and the amplified fragment was cleaved using the DdeI (C\TNAG) restriction enzyme (New England Biolabs, Ipswich, MA, USA). The characterization of $\beta^{\mathrm{S}}$-haplotypes was determined by polymerase chain reaction-restriction fragment length polymorphism with the following polymorphic sites being analyzed: $H B G 2$ (HindIII), HBGI (HindIII), HBBP (HincII), 3'HBBP (HincII) and 5'HBB (Hinf I) as previously described. ${ }^{43}$

\section{Cell count, red cell index and bilirubin measurement}

A complete blood count was performed by an automated system that differentiates blood cells by flow cytometry and quantifies $\mathrm{Hb}$ by spectrophotometry (Cell-Dyn Ruby, Abbott Laboratories, Chicago, IL, USA). The parameters measured were: red blood cell count (RBC), $\mathrm{Hb}$, hematocrit (Ht) and absolute reticulocyte count (Absol. Ret.). Indirect bilirubin (IB) levels, also known as unconjugated bilirubin, were obtained by the 2,4-dichlorophenyl diazonium method (AU680 Chemistry System, Beckman Coulter Inc., Jersey, NJ, USA).

\section{Biochemical analysis}

Lipid peroxidation levels in plasma were evaluated using the thiobarbituric acid reactive species test (TBARS). Some lipid peroxidation products such as malondialdehyde react with thiobarbituric acid in a heated acid medium to form a chromogen with high molar absorptivity in the $535 \mathrm{~nm}$ visible spectrum; ${ }^{44}$ the reference value is $500.0 \mathrm{ng} \mathrm{ml}^{-1} .{ }^{45}$ Glycoprotein plasma levels were measured by enzyme-linked immunosorbent assay using the double antibody sandwich method according to the manufacturer's instructions: EPO (catalog number DEP00R\&D Systems, Inc., Minneapolis, MN, USA), HP (version 3 L15.0-15-Genway Biotech) and HPx (Version 2 L14.0-1-Genway Biotech, San Diego, CA, USA). The reference values are: $3.1-14.9 \mathrm{mU} \mathrm{ml}^{-1}$ for EPO; $360-1950 \mathrm{ng} \mathrm{ml}^{-1}$ for HP and $800-1000 \mathrm{ng} \mathrm{ml}^{-1}$ for HPx.

\section{Statistical analysis}

Statistical analyses were performed using the Statistica 9.0 software (StatSoft Inc., Tulsa, OK, USA). The data were tested for normality and homogeneity of variances using the Shapiro-Wilk and Levene tests. The subgroups that confirmed the premises (parametric data) were compared by $t$-Student test or one-way analysis of variance followed by Fisher's post hoc test. However, the subgroups that did not confirm the premises (nonparametric data) were compared using the Mann-Whitney or Kruskal-Wallis test followed by the Student-Newman-Keuls post hoc test. The Pearson correlation was used for parametric data and Spearman test for nonparametric data to assess the degree of association between the study variables. Data are presented as means \pm standard deviation and differences with a $P$-value $<0.05$ were considered significant. Data of TBARS were converted to $\log 10$ to use parametric tests.

\section{RESULTS}

\section{Study group characterization}

The 527 SCA patients were characterized for the $\beta^{S}$-haplotypes being 295 (56\%) Bantu/Bantu, 128 (24.3\%) Bantu/Benin, 44 (8.3\%) Bantu/ Atypical, 36 (6.84\%) Benin/Benin, 10 (1.9\%) Benin/Atypical, 3 (0.57\%) Bantu/Camerron, 3 (0.57\%) Benin/Camerron, 3 (0.57\%) Atypical/Atypical, 2 (0.38\%) Bantu/Saudi, 2 (0.38\%) Bantu/Senegal and $1(0.19 \%)$ Benin/Saudi. After characterization, the study group was selected on the basis of the exclusion and inclusion criteria. Thus, the study group finally consisted of 48 patients (20 males and 28 females) with a mean age of 31.2 years (range: 6-63 years) and mean duration of HC therapy of $895.3 \pm 621.0$ days (range: $240-3156$ days). The patients were divided into three sample subgroups according to

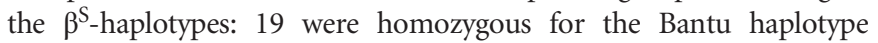
(Bantu/Bantu), 18 had the Bantu/Benin haplotype and 11 were homozygous for the Benin haplotype (Benin/Benin). Besides the criteria adopted, we evaluated the mean age and the duration of $\mathrm{HC}$ therapy between sample subgroups and compared the biomarker levels between genders to verify whether these variables influence the biomarker parameters evaluated (TBARS, Hb F, EPO, HP, HPx, $\mathrm{RBC}, \mathrm{Hb}, \mathrm{Ht}$, Absol. Ret. count and IB). The results were similar in all the three studied subgroups and between gender as shown in 
Table 1 Evaluation of possible confounding variables of the study

\begin{tabular}{|c|c|c|c|c|c|}
\hline & $\begin{array}{c}\text { Bantu/Bantu } \\
(\mathrm{n}=19) M e a n \pm \text { s.d. }\end{array}$ & $\begin{array}{c}\text { Bantu/Benin } \\
(\mathrm{n}=18) \text { Mean } \pm \text { s.d. }\end{array}$ & $\begin{array}{c}\text { Benin/Benin } \\
(\mathrm{n}=11) \text { Mean } \pm \text { s.d. }\end{array}$ & P-value & $\begin{array}{c}\text { Total } \\
(\mathrm{n}=48) \text { Mean } \pm \text { s.d. }\end{array}$ \\
\hline Age & $33.63 \pm 16.64$ & $28.83 \pm 15.52$ & $30.7 \pm 19.05$ & $0.68^{a}$ & $31.16 \pm 16.58$ \\
\hline \multicolumn{2}{|c|}{ Hemolytic and oxidative stress biomarkers } & Woman $(\mathrm{n}=28)$ Mean \pm s.d. & \multicolumn{2}{|c|}{$\operatorname{Man}(\mathrm{n}=20)$ Mean \pm s.d. } & P-value \\
\hline $\mathrm{Hb} F(\%)$ & & $13.2 \pm 7.9$ & \multicolumn{2}{|c|}{$11.5 \pm 7.4$} & $0.76^{\mathrm{a}}$ \\
\hline EPO $\left(m U I m l^{-1}\right)$ & & $80.3 \pm 42.9$ & \multicolumn{2}{|c|}{$118.9 \pm 96.7$} & $0.24^{b}$ \\
\hline $\mathrm{HP}\left(\mathrm{ng} \mathrm{ml^{-1 }}\right)$ & & $73.3 \pm 4.52$ & \multicolumn{2}{|c|}{$75.3 \pm 3.41$} & $0.10^{\mathrm{a}}$ \\
\hline $\mathrm{HPx}\left(\mathrm{ng} \mathrm{ml}^{-1}\right)$ & & $190.9 \pm 29.9$ & \multicolumn{2}{|c|}{$205.6 \pm 38.8$} & $0.15^{\mathrm{b}}$ \\
\hline $\operatorname{RBC}\left(\left.M \mu\right|^{-1}\right)$ & & $2.42 \pm 0.55$ & \multicolumn{2}{|c|}{$2.44 \pm 0.53$} & $0.88^{a}$ \\
\hline $\mathrm{Hb}\left(\mathrm{gdl}^{-1}\right)$ & & $8.37 \pm 1.6$ & \multicolumn{2}{|c|}{$8.51 \pm 1.11$} & $0.10^{\mathrm{a}}$ \\
\hline
\end{tabular}

Abbreviations: Absol. Ret., absolute reticulocyte count; EPO, erythropoietin; Hb, hemoglobin; Hb F, fetal hemoglobin; HC, hydroxycarbamide; HP, haptoglobin; HPx, hemopexin; Ht, hematocrit; $\mathrm{IB}$, indirect bilirubin; RBC, red blood cell; TBARS, thiobarbituric acid reactive species.

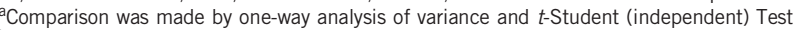

${ }^{b}$ Comparison was performed by Kruskal-Wallis and Mann-Whitney tests.

Table 2 Lipid peroxidation and hemolysis levels of the subgroups

\begin{tabular}{|c|c|c|c|c|c|c|}
\hline $\begin{array}{l}\text { Hemolytic and oxidative } \\
\text { stress biomarkers }\end{array}$ & $\begin{array}{c}\text { Bantu/Bantu }(\mathrm{n}=19) \\
\text { Mean } \pm \text { s.d. }\end{array}$ & $\begin{array}{c}\text { Bantu/Benin }(\mathrm{n}=18) \\
\text { Mean } \pm \text { s.d. }\end{array}$ & $\begin{array}{c}\text { Benin/Benin }(\mathrm{n}=11) \\
\text { Mean } \pm \text { s.d. }\end{array}$ & P-value & Total & Reference value \\
\hline TBARS (ng ml-1) & $1419.31 \pm 638.35^{a}$ & $2010.16 \pm 1041.75^{a, b}$ & $3060.45 \pm 2168.41^{b}$ & $0.01^{a}$ & $2016.97 \pm 1395.81$ & 440.0 \\
\hline EPO $\left(m U I \mathrm{ml}^{-1}\right)$ & $103.74 \pm 92.95$ & $93.77 \pm 61.15$ & $88.23 \pm 48.85$ & $0.48^{b}$ & $96.45 \pm 72.18$ & $3.1-14.9$ \\
\hline $\mathrm{HP}\left(\mathrm{ng} \mathrm{ml^{-1 }}\right)$ & $72.8 \pm 5.71^{a}$ & $75.08 \pm 2.61^{b}$ & $74.94 \pm 2.38^{a, b}$ & $0.01^{\mathrm{b}}$ & $74.15 \pm 4.17$ & $360-1950$ \\
\hline $\mathrm{HPx}\left(\mathrm{ng} \mathrm{ml}^{-1}\right)$ & $193.22 \pm 34.84$ & $198.29 \pm 34.52$ & $201 \pm 35.69$ & $0.82^{\mathrm{b}}$ & $197.06 \pm 34.33$ & $800-1000$ \\
\hline $\mathrm{Ht}(\%)$ & $22.89 \pm 3.68$ & $24.80 \pm 4.16$ & $24.03 \pm 4.52$ & $0.36^{a}$ & $23.87 \pm 4.06$ & $36.0-53.0$ \\
\hline Absol. Ret. $\left(K \mu l^{-1}\right)$ & $203.28 \pm 76.91$ & $189.19 \pm 71.57$ & $205.35 \pm 88.02$ & $0.81^{a}$ & $198.47 \pm 76.29$ & $<150.0$ \\
\hline $\mid \mathrm{B}\left(\mathrm{mg} \mathrm{dl^{-1 }}\right)$ & $2.24 \pm 1.53$ & $1.77 \pm 2.06$ & $1.77 \pm 1.66$ & $0.21^{b}$ & $1.95 \pm 1.75$ & $<0.8$ \\
\hline
\end{tabular}

Abbreviations: Absol. Ret., absolute reticulocyte count; EPO, erythropoietin; Hb, hemoglobin; Hb F: fetal hemoglobin; HP, haptoglobin; HPx, hemopexin; Ht, hematocrit; IB, indirect bilirubin; RBC, red blood cell; TBARS, thiobarbituric acid reactive species.

Bold number indicate statistical differences.

Different letters indicate statistical differences.

aComparison was performed by one-way analysis of variance followed by Fisher's post hoc test.

${ }^{b}$ Comparison was made by Kruskal-Wallis followed by Student-Newman-Keuls post hoc test.

Table 1. Thus, neither of these parameters interfered in the biomarker levels.

\section{Hemolytic and oxidative stress parameters}

Hematological variables and hemolytic and oxidative stress biomarkers were evaluated for each one of the three subgroups to confirm whether the phenotypic expression of patients influenced the parameters. There were statistically significant differences for the lipid peroxidation and HP levels but not for the other biomarkers (Hb F, EPO, HPx, RBC, $\mathrm{Hb}, \mathrm{Ht}$, Absol. Ret. count and IB) as shown in Table 2. TBARS levels were 2.15 times higher in patients with the Benin/Benin haplotype than in patients with the Bantu/Bantu haplotype (Figure 1a). The HP levels were slightly higher in patients with the Bantu/Benin haplotype compared with the Bantu/Bantu haplotype (Figure 1b).
Association of biomarkers in the subgroups

The association degrees between the hemolytic and oxidative stress biomarkers evaluated in this study were calculated for each subgroup to better understand the influence of haplotypes (Table 3). The Bantu/Bantu subgroup showed a positive correlation between the TBARS levels and the Absol. Ret. Count $(r=0.46 ; P$-value $=0.04)$ (Figure 2-a1) and a negative correlation between the EPO and IB levels $(r=-0.75 ; P$-value $<0.01)$ (Figure 2 -a2). The Bantu/Benin subgroup showed a positive correlation between the HPx and HP levels $(r=0.59 ; P$-value $<0.01)$ (Figure 2-b1) and $\mathrm{Hb} \mathrm{F}$ levels $(r=0.53$; $P$-value $=0.02) \quad$ (Figure 2-b2). We observed negative correlations in the Benin/Benin subgroup between the RBC and EPO levels $(r=-0.89 ; P$-value $<0.01)$ (Figure $2-c 1)$. There was also a positive correlation between the Absol. Ret. Count and the HP level $(r=0.69$; $P$-value $=0.01)$ (Figure $2-c 2)$ in this subgroup. 

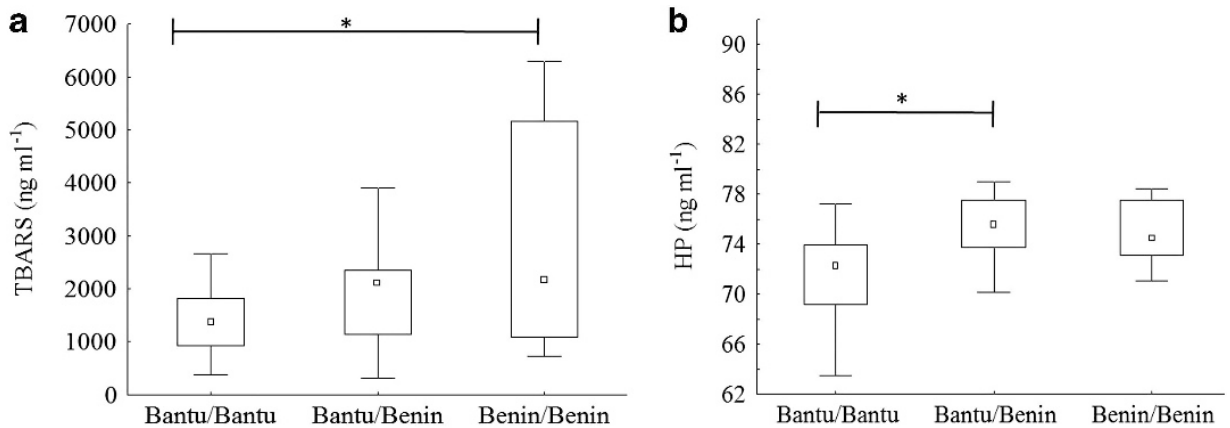

Figure 1 Lipid peroxidation and Hp levels among samples subgroups. (a) Lipid peroxidation showed higher levels in those patients with Benin/Benin genotype compared with those with Bantu/Bantu genotype ( $P=0.013$; one-way analysis of variance followed by Fisher's post hoc test). (b) Hp levels were lower in patients with Bantu/Bantu genotype compared with those with Bantu/Benin genotype $(P=0.017$; Kruskal-Wallis followed by Student-Newman-Keuls post hoc test).

Table 3 The association degrees between biomarkers in the different subgroups

\begin{tabular}{|c|c|c|c|c|c|}
\hline \multirow[b]{2}{*}{$\begin{array}{l}\text { Sample } \\
\text { subgroups }\end{array}$} & \multirow[b]{2}{*}{$\begin{array}{l}\text { Hemolytic and oxidative } \\
\text { stress biomarkers }\end{array}$} & \multicolumn{4}{|c|}{ Correlation results ( $\mathrm{r}$ (P-value)) } \\
\hline & & $\begin{array}{c}\text { TBARS } \\
\text { (ng m/-1) (P-value) }\end{array}$ & $\begin{array}{c}E P O \\
\left(m / \cup m l^{-1}\right)(\mathrm{P}-\text { value })\end{array}$ & $\begin{array}{c}H P \\
\left(n g m l^{-1}\right)(\mathrm{P}-\text { value })\end{array}$ & $\begin{array}{c}H P x \\
\left(n g m l^{-1}\right)(P-v a l u e)\end{array}$ \\
\hline \multicolumn{6}{|c|}{ Bantu/Bantu } \\
\hline & $\mathrm{Hb} F(\%)$ & $-0.04(0.86)^{a}$ & $0.23(0.33)$ & $0.10(0.66)$ & $0.32(0.17)$ \\
\hline & EPO (mlU ml-1) & $0.07(0.74)$ & - & $0.33(0.16)$ & $0.40(0.08)$ \\
\hline & $\mathrm{HP}\left(\mathrm{ng} \mathrm{ml^{-1 }}\right)$ & $-0.12(0.59)$ & $0.33(0.16)$ & - & $-0.007(0.97)$ \\
\hline & $\operatorname{HPx}($ ng ml-1) & $-0.08(0.72)$ & $0.40(0.08)$ & $-0.007(0.97)$ & - \\
\hline & $\operatorname{RBC}\left(M \mu l^{-1}\right)$ & $-0.02(0.91)^{a}$ & $-0.33(0.16)$ & $0.03(0.88)$ & $-0.08(0.73)$ \\
\hline & $\mathrm{Hb}\left(\mathrm{g} \mathrm{dl}^{-1}\right)$ & $-0.12(0.61)^{a}$ & $-0.03(0.87)$ & $0.10(0.67)$ & $0.34(0.14)$ \\
\hline & $\mathrm{Ht}(\%)$ & $-0.09(0.69)^{a}$ & $-0.17(0.48)$ & $0.09(0.70)$ & $0.27(0.26)$ \\
\hline & Absol. Ret. $\left(\mathrm{K} \mu \mathrm{l}^{-1}\right)$ & $0.46(0.04)^{\mathrm{a}}$ & $0.02(0.90)$ & $0.34(0.15)$ & $-036(0.12)$ \\
\hline & $\mathrm{IB}\left(\mathrm{mg} \mathrm{dl}^{-1}\right)$ & $0.08(0.72)$ & $-0.75(<0.01)$ & $-0.40(0.08)$ & $-0.16(0.49)$ \\
\hline \multicolumn{6}{|c|}{ Bantu/Benin } \\
\hline & $\mathrm{Hb} F(\%)$ & $0.12(0.61)^{a}$ & $0.062(0.80)$ & $0.19(0.44)$ & $0.53(0.02)$ \\
\hline & $\mathrm{EPO}\left(\mathrm{mlU} \mathrm{ml} \mathrm{m}^{-1}\right)$ & $0.18(0.46)$ & - & $0.22(0.36)$ & $0.20(0.40)$ \\
\hline & $\mathrm{HP}\left(\mathrm{ng} \mathrm{ml^{-1 }}\right)$ & $-0.24(0.31)$ & $0.22(0.36)$ & - & $0.59(<0.01)$ \\
\hline & $\operatorname{HPx}\left(n g \mathrm{ml}^{-1}\right)$ & $0.14(0.55)$ & $0.20(0.40)$ & $0.59(<0.01)$ & - \\
\hline & $\operatorname{RBC}\left(M \mu l^{-1}\right)$ & $-0.35(0.15)^{a}$ & $-0.33(0.16)$ & $-0.38(0.11)$ & $-0.20(0.42)$ \\
\hline & $\mathrm{Hb}\left(\mathrm{g} \mathrm{dl}^{-1}\right)$ & $0.14(0.56)^{a}$ & $-0.10(0.68)$ & $-0.25(0.30)$ & $0.20(0.40)$ \\
\hline & $\mathrm{Ht}(\%)$ & $0.06(0.79)^{a}$ & $-0.17(0.48)$ & $-0.35(0.14)$ & $0.10(0.67)$ \\
\hline & Absol. Ret. $\left(K_{\mu l^{-1}}\right)$ & $0.19(0.43)^{a}$ & $0.003(0.99)$ & $-0.19(0.44)$ & $-0.19(0.44)$ \\
\hline & $\mathrm{IB}\left(\mathrm{mg} \mathrm{dl}{ }^{-1}\right)$ & $0.35(0.14)$ & $0.20(0.42)$ & $-0.15(0.53)$ & $-0.23(0.35)$ \\
\hline \multicolumn{6}{|c|}{ Benin/Benin } \\
\hline & $\mathrm{Hb} F(\%)$ & $0.01(0.95)^{a}$ & $0.10(0.75)$ & $-0.48(0.13)$ & $0.18(0.58)$ \\
\hline & $\mathrm{EPO}\left(\mathrm{mIU} \mathrm{ml^{-1 } )}\right.$ & $-0.018(0.95)$ & - & $0.29(0.38)$ & $0.27(0.41)$ \\
\hline & $\mathrm{HP}\left(\mathrm{ng} \mathrm{ml}^{-1}\right)$ & $0.031(0.92)$ & $0.29(0.38)$ & - & $0.23(0.49)$ \\
\hline & $\operatorname{HPx}\left(n g \mathrm{ml}^{-1}\right)$ & $-0.55(0.14)$ & $0.27(0.41)$ & $0.23(0.49)$ & - \\
\hline & $\mathrm{RBC}\left(\mathrm{M} \mu \mathrm{I}^{-1}\right)$ & $-0.05(0.88)^{a}$ & $-0.89(<0.01)$ & $-0.21(0.52)$ & $0.11(0.72)$ \\
\hline & $\mathrm{Hb}\left(\mathrm{gdl}^{-1}\right)$ & $-0.04(0.89)^{a}$ & $-0.49(0.12)$ & $-0.57(0.06)$ & $0.30(0.35)$ \\
\hline & $\mathrm{Ht}(\%)$ & $-0.08(0.81)^{\mathrm{a}}$ & $-0.50(0.11)$ & $-0.46(0.14)$ & $0.26(0.43)$ \\
\hline & Absol. Ret. $\left(\mathrm{K}_{\mu \mathrm{I}^{-1}}\right)$ & $0.07(0.82)$ & $-0.34(0.29)$ & $0.69(0.01)$ & $0.14(0.66)$ \\
\hline & $\mathrm{IB}\left(\mathrm{mg} \mathrm{dl^{-1 } )}\right.$ & $0.20(0.55)$ & $0.17(0.61)$ & $0.48(0.13)$ & $-0.03(0.91)$ \\
\hline
\end{tabular}

Abbreviations: Absol. Ret., absolute reticulocyte count; EPO, erythropoietin; Hb, hemoglobin; Hb F, fetal hemoglobin; HP, haptoglobin; HPx, hemopexin; Ht, hematocrit; IB, indirect bilirubin; $\mathrm{RBC}$, red blood cell; TBARS, thiobarbituric acid reactive species.

Bold number indicate statistical differences.

aComparisons were made by Pearson's correlation; comparisons made by Spearman's rank correlation were not marked.

\section{DISCUSSION}

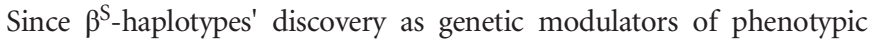
expression in SCA, several studies have been developed to determine the effect of haplotypes on SCA patients hematological and clinical features, but studies associating haplotypes with oxidative stress markers are still scarce. ${ }^{25}$ This study, to our knowledge, is the first study that evaluated the expression of hemolytic and oxidative stress biomarkers in a group of Brazilian SCA patients treated with HC. The 


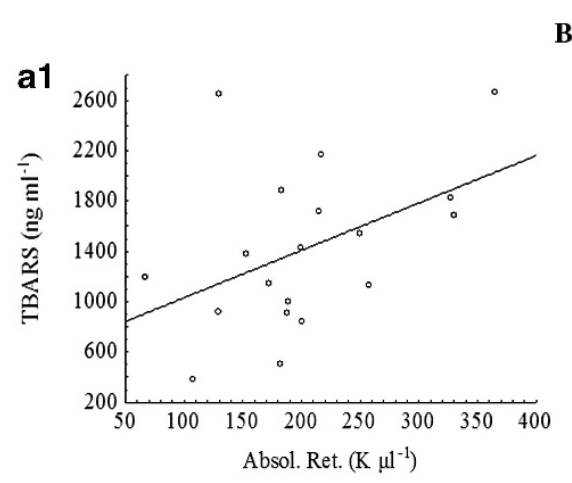

\section{Bantu/Bantu}
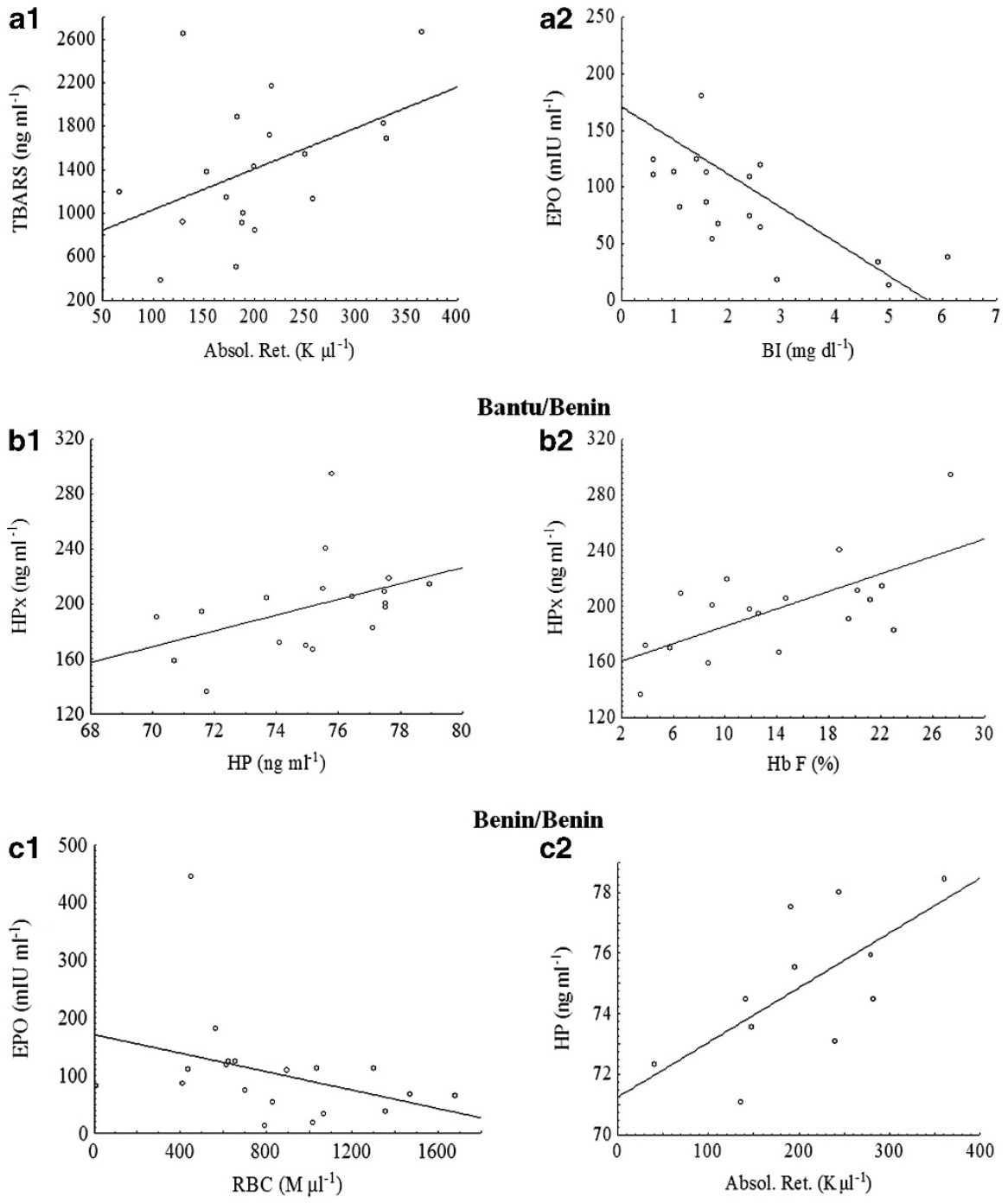

Figure 2 The association degree between biomarkers. (a1) Positive correlation between TBARS and Absol. Ret. in the Bantu/Bantu subgroup ( $r=0.46$; $P=0.04$; Pearson's test); (a2) negative correlation between Epo and $\mathrm{BI}$ in the Bantu/Bantu subgroup ( $r=-0.75 ; P<0.01$; Spearman's rank test); (b1) positive correlation between $\mathrm{Hpx}$ and $\mathrm{Hp}$ in the Bantu/Benin subgroup ( $r=0.59 ; P<0.01$; Spearman's rank test); (b2) positive correlation between Hpx and $\mathrm{Hb} F$ in the Bantu/Benin subgroup ( $r=0.53$; $P=0.02$; Spearman's rank test); (c1) negative correlation between Epo and RBC in the Benin/Benin subgroup $(r=-0.89 ; P<0.01$; Spearman's rank test) and (c2) positive correlation between $\mathrm{Hp}$ and Absol. Ret. in the Benin/Benin subgroup( $r=0.69 ; P=0.01$; Spearman's rank test).

inclusion criteria were strict to identify only possible influence of $\beta^{\mathrm{S}}$-haplotypes on response to HC treatment. The results showed that the presence of Bantu and/or Benin haplotypes conferred a differential expression of the hemolytic and oxidative stress biomarkers evaluated in this study.

Since the first evidence of the $\mathrm{HC}$ influence in increasing $\mathrm{Hb} \mathrm{F}$ levels in SCA patients and the consequent improvement in the prognosis of the disease, ${ }^{24,46,47}$ several studies have shown the involvement of $\beta^{S}$-haplotypes in the different responses to drug use. The Bantu haplotype was correlated to a worse clinical status because of low $\mathrm{Hb} \mathrm{F}$ levels and to increased oxidative stress, inflammation and DNA damage. ${ }^{37,38,48}$ On the other hand, two studies showed that the presence of the Bantu haplotype was not always correlated with a worse prognosis. ${ }^{27,36}$ Vicari et al. ${ }^{36}$ found a significant increase in $\mathrm{Hb} \mathrm{F}$ levels in SCA homozygous patients for the Bantu haplotype and on HC therapy. Silva et al. ${ }^{27}$ showed that SCA patients with the Bantu haplotype, in at least one chromosome, treated with $\mathrm{HC}$ had higher $\mathrm{Hb}$ F levels compared with patients with the Bantu haplotype in at least one chromosome but not taking HC and those without any Bantu haplotype treated or not treated with HC. In the present study, we found similar $\mathrm{Hb}$ F levels among the studied subgroups. Interestingly, the patients with the Bantu/Bantu haplotype showed a mean amount of $\mathrm{Hb}$ F levels (10\%) even greater than those found by Vicari et al. and Silva et al. This result reinforces a better response of Bantu/Bantu patients under HC treatment.

We observed another interesting result in the Bantu/Bantu subgroup that was the lower lipid peroxidation level when compared with the Benin/Benin subgroup. The TBARS levels presented, approximately, two times higher in the subgroup Benin/Benin than the subgroup Bantu/Bantu. Although the Bantu/Bantu subgroup have presented less lipid peroxidation levels, the levels observed in this 
subgroup was higher than that found by our team in a control group. ${ }^{44}$ In SCA patients, reactive oxygen species are generated because of various mechanisms, including polymerization and depolymerization of $\mathrm{Hb} \mathrm{S}$ in $\mathrm{RBC}$, with the release of free $\mathrm{Hb}$ in plasma and injury resulting from the numerous ischemia and reperfusion events. ${ }^{8,49,50}$ Probably the reactive oxygen species generated in the Bantu/Bantu patients in this study resulted in RBC membrane lysis. Even though this subgroup had the lowest lipid peroxidation level, approximately 50\% of the TBARS was related to Absol. Ret. count and thus reflects a physiological response to hemolytic events. This finding was corroborated by low HP levels compared with the Bantu/Benin subgroup. The low HP levels can indicate hemolysis because this glycoprotein is used for scavenger-free Hb. ${ }^{15,51-54}$ The high hemolytic levels associated to the Bantu/Bantu haplotype may be explained, in addition to lipid peroxidation, by the hemolytic markers. The increase in IB levels was negatively correlated with the EPO levels. This result may indicate the EPO consumption for the production of new RBCs, however, a direct correlation between EPO consumption and the production of RBC was not observed. Taking into consideration our results along with an ineffective erythropoiesis in SCA patients that contributes to SCA pathophysiology, ${ }^{21,22}$ we suggest that EPO synthesis in Bantu/Bantu patients did not meet the demand of RBC production probably due to the high hemolytic rate.

In Benin/Benin patients, we observed less hemolytic rate than Bantu/Bantu ones. The decrease in EPO levels with increased RBC counts may be indicative of EPO consumption for new RBC synthesis. We also observed a concomitant increase in the HP level and Absol. Ret. count. An increased Absol. Ret. count indicates a response of the bone marrow to meet any hemolytic damage, thus decreasing hemolysis degree with a consequent maintenance of high HP levels in the plasma. Despite TBARS levels being higher in this sample subgroup, there was no correlation between TBARS and the evaluated hemolytic biomarkers. Therefore, probably the lipid peroxidation levels observed in this subgroup sample reflected the systemic oxidative stress. ${ }^{55}$

Patients in the Bantu/Benin subgroup showed a low hemolytic rate and moderate oxidative stress. HP levels were slightly higher in this subgroup compared with patients with the Bantu/Bantu haplotype. The HP results along with HPx levels obtained confirm the low hemolytic index in the Bantu/Benin subgroup. Another interesting result for this subgroup was related to the $\mathrm{Hb} F$ levels, which were positively correlated to the HPx levels. This correlation may be involved in a well-described protection mechanism by which $\mathrm{Hb} \mathrm{F}$ levels contribute to reduce $\mathrm{Hb} \mathrm{S}$ polymerization, ${ }^{56}$ thus improving hemolytic ${ }^{57}$ and oxidative stress outcomes. ${ }^{58-60}$

We adopted rigorous inclusion and exclusion criteria and wellcharacterized baseline outcomes of the SCA patients, for the study subgroup composition, allowing us to suggest a haplotype modulation of hemolytic and oxidative markers evaluated. The two haplotypes investigated differ from each other intrinsically by the presence or absence of two polymorphic sites. The Bantu haplotype has a polymorphic site in the G-gamma globin gene (HBG2-HindIII) and Benin a polymorphic site on the $3^{\prime}$ end of the beta pseudogene ( $3^{\prime}$ HBBP-HincII). Considering that a polymorphism located in a pseudogene will not directly affect the production of a corresponding globin, it is likely that the variations observed in the biomarkers evaluated are related to the active mutation in the HBG2.

According to our findings, we believe that the hemolytic and oxidative stress biomarkers evaluated in this study were influenced by the Bantu and Benin haplotypes in SCA patients undergoing HC treatment. The oxidative stress was less in patients homozygous for the
Bantu haplotype, while hemolytic stress was less in those homozygous for the Benin haplotype. The dual inheritance (Bantu/Benin) was associated to intermediated biomarkers index owing to the balance between the genetic factors of each haplotype. We suggest that differences in the polymorphic sites are the key element to understanding the modulation of haplotypes in respect to the phenotypic expression of SCA patients.

\section{CONFLICT OF INTEREST}

The authors declare no conflict of interest.

\section{ACKNOWLEDGEMENTS}

We would like to thank Dr Débora Aparecida Pires de Campos Zuccari of the Sao Jose do Rio Preto Medical School (FAMERP) for her technical assistance in the ELISA analysis and the Foundation for Research Support of the State of Sao Paulo (FAPESP process number 2011/14168-5) for financial support.

1 Kato, G. J., Gladwin, M. T. \& Steinberg, M. H. Deconstructing sickle cell disease: Reappraisal of the role of hemolysis in the development of clinical subphenotypes. Blood Rev. 21, 37-47 (2007).

2 Rees, D. C., Williams, T. N. \& Gladwin, M. T. Sickle-cell disease. Lancet 376, 2018-2031 (2010).

3 Bensinger, T. A. \& Gillette, P. N. Hemolysis in sickle cell disease. Arch. Intern. Med. 133, 624-631 (1974).

4 Hebbel, R. P. Reconstructing sickle cell disease: A data-based analysis of the 'hyperhemolysis paradigm' for pulmonary hypertension from the perspective of evidence-based medicine. Am. J. Hematol. 86, 123-154 (2011).

5 Steinberg, M. H. Sickle cell anemia, the first molecular disease: overview of molecular etiology, pathophysiology, and therapeutic approaches. ScientificWorldJournal 8, 1295-1324 (2008)

6 Gozzelino, R., Jeney, V. \& Soares, M. P. Mechanisms of cell protection by heme oxygenase-1. Annu. Rev. Pharmacol. Toxicol. 50, 323-354 (2010).

7 Schaer, D. J., Buehler, P. W., Alayash, A. I., Belcher, J. D. \& Vercellotti, G. M. Hemolysis and free hemoglobin revisited: Exploring hemoglobin and hemin scavengers as a novel class of therapeutic proteins. Blood 121, 1276-1284 (2013).

8 Rifkind, J. M., Mohanty, J. G. \& Nagababu, E. The pathophysiology of extracellular hemoglobin associated with enhanced oxidative reactions. Front. Physiol. $\mathbf{5}$, 1-7 (2015).

9 Gizi, A., Papassotiriou, I., Apostolakou, F., Lazaropoulou, C., Papastamataki, M., Kanavaki, I. et al. Assessment of oxidative stress in patients with sickle cell disease: The glutathione system and the oxidant-antioxidant status. Blood Cells Mol. Dis. 46, 220-225 (2011).

10 Schaer, C. A., Deuel, J. W., Bittermann, A. G., Rubio, I. G., Schoedon, G., Spahn, D.R. et al. Mechanisms of haptoglobin protection against hemoglobin peroxidation triggered endothelial damage. Cell Death Differ. 20, 1569-1579 (2013).

11 Kristiansen, M., Graversen, J.H., Jacobsen, C., Sonne, O., Hoffman, H. J., Law, S. K. A. et al. Identification of the haemoglobin scavenger receptor. Nature 409 , 198-201 (2001)

12 Schaer, D. J., Alayash, A. I. \& Buehler, P. W. Gating the radical hemoglobin to macrophages: the anti-inflammatory role of CD163, a scavenger receptor. Antioxid. Redox Signal. 9, 991-999 (2007).

13 Chiabrando, D., Vinchi, F., Fiorito, V., Mercurio, S. \& Tolosano, E. Heme in pathophysiology: a matter of scavenging, metabolism and trafficking across cell membranes. Front. Pharmacol. 5, 1-24 (2014).

14 Schaer, D. J. \& Alayash, A. I. Clearance and control mechanisms of hemoglobin from cradle to grave. Antioxid. Redox Signal. 12, 181-184 (2010).

15 Reiter, C. D., Wang, X., Tanus-Santos, J. E., Hogg, N., Cannon, R. O., Schechter, A. N. et al. Cell-free hemoglobin limits nitric oxide bioavailability in sickle-cell disease. Nat. Med. 8, 1383-1389 (2002).

16 Moller, H. J., Nielsen, M. J., Bartram, J., Dick, M. C., Height, S. E., Moestrup, S. K. et al. Soluble CD163 levels in children with sickle cell disease. Br. J. Haematol. 153, 105-110 (2011).

17 Rees, D. C. \& Gibson, J. S. Biomarkers in sickle cell disease. Br. J. Haematol. 156, 433-445 (2012).

18 Haase, V. H. Hypoxic regulation of erythropoiesis and iron metabolism. Am. J. Physiol. Renal Physiol. 299, F1-F13 (2010).

19 Jelkmann, W. Physiology and pharmacology of erythropoietin. Transfus. Med. Hemother. 40, 302-309 (2013).

20 Zhang, Y., Wang, L., Dey, S., Alnaeeli, M., Suresh, S., Roger, H. et al. Erythropoietin action in stress response, tissue maintenance and metabolism. Int. J. Mol. Sci. 15, 10296-10333 (2014).

21 Fibach, E. \& Rachmilewitz, E. A. Does erythropoietin have a role in the treatment of $\beta$-hemoglobinopathies? Hematol. Oncol. Clin. North Am. 28, 249-263 (2014). 
22 Pulte, E. D., McKenzie, S. E., Caro, J. \& Ballas, S. K. Erythropoietin levels in patients with sickle cell disease do not correlate with known inducers of erythropoietin Hemoglobin 38, 385-389 (2014).

23 Cokic, V. P., Smith, R. D., Beleslin-Cokic, B. B., Njoroge, J.M., Miller, J. L., Gladwin, M. T. et al. Hydroxyurea induces fetal hemoglobin by the nitric oxide - dependent activation of soluble guanylyl cyclase. J. Clin. Invest. 111 231-239 (2003)

24 Lou, T. F., Singh, M., Mackie, A., Li, W. \& Pace, B. S. Hydroxyurea generates nitric oxide in human erythroid cells: mechanisms for gamma-globin gene activation. Exp. Biol. Med. 234, 1374-1382 (2009).

25 Ware, R. E. \& Aygun, B. Advances in the use of hydroxyurea. Hematology Am. Soc. Hematol. Educ. Program 62-69 (2009).

26 Bakanay, S. M., Dainer, E., Clair, B., Adekile, A., Daitch, L., Wells, L. et al. Mortality in sickle cell patients on hydroxyurea therapy. Blood 105, 545-547 (2005).

27 Silva, D. G., Belini-Junior, E., Carrocini, G. C., Torres, L., Ricci-Junior, O., Lobo, C. L. et al. Genetic and biochemical markers of hydroxyurea therapeutic response in sickle cell anemia. BMC Med. Genet. 14, 108 (2013).

28 Pagnier, J., Mears, G., Dunda-Belkhodja, O., Schaefer-Rego, K. E., Beldjord, C., Nagel, R. L. et al. Evidence for the multicentric origin of the sickle cell hemoglobin gene in Africa. Proc. Natl Acad. Sci. USA 81, 1771-1773 (1984).

29 Kulozik, A. E., Wainscoat, J. S., Serjeant, G.R., Kar, B. C., Al-Awamy, B., Essan, G. J. F. et al. Geographical survey of beta S-globin gene haplotypes: evidence for an independent Asian origin of the sickle-cell mutation. Am. J. Hum. Genet. 39, 239-244 (1986).

30 Lapouméroulie, C., Dunda, O., Ducrocq, R., Trabuchet, G., Mony-Lobé, M., Bodo, J. M. et al. A novel sickle cell mutation of yet another origin in Africa: the Cameroon type. Hum. Genet. 89, 333-337 (1992).

31 Adorno, E. V., Zanette, A., Lyra, I., Souza, C. C., Santos, L. F., Menezes, J. F. et al. The beta-globin gene cluster haplotypes in sickle cell anemia patients from Northeast Brazil: a clinical and molecular view. Hemoglobin 28, 267-271 (2004).

32 Cabral, C. H., Serafim, E. S., Medeiros, W. R., Fernandes, T. A., Kimura, E. M. Costa, F. F. et al. Determination of $\beta^{S}$ haplotypes in patients with sickle-cell anemia in the state of Rio Grande do Norte, Brazil. Genet. Mol. Biol. 34, 421-424 (2011).

33 Okumura, J. V., de Lobo, C.L. \& Bonini-Domingos, C. R. Beta-S globin haplotypes in patients with sickle cell anemia: one approach to understand the diversity in Brazil. Rev. Bras. Hematol. Hemoter. 35, 71-72 (2013).

34 Powars, D. R. Beta s-gene-cluster haplotypes in sickle cell anemia. Clinical and hematologic features. Hematol. Oncol. Clin. North Am. 5, 475-493 (1991).

35 Powars, D. \& Hiti, A. Sickle cell anemia. Beta s gene cluster haplotypes as genetic markers for severe disease expression. Am. J. Dis. Child. 147, 1197-1202 (1993).

36 Vicari, P., De Mello, A. B. \& Figueiredo, M. S. Effects of hydroxyurea in a population of Brazilian patients with sickle cell anemia. Am. J. Hematol. 78, 243-244 (2005)

37 Silva-Rocha, L. B., Dias Elias, D. B., Barbosa, M. C., Bandeira, I. C. J. \& Gonçalves, R. P. DNA damage in leukocytes of sickle cell anemia patients is associated with hydroxyurea therapy and with $\mathrm{HBB}^{*} \mathrm{~S}$ haplotype. Mutat. Res. 749, 48-52 (2012).

38 Bandeira, I. C., Rocha, L. B., Barbosa, M. C., Elias, D. B., Querioz, J. A., Freitas, M. V. et al. Chronic inflammatory state in sickle cell anemia patients is associated with HBB*S haplotype. Cytokine 65, 217-221 (2014).

39 Sambrook, J., Fritsch, E. F. \& Maniatis, T. Molecular Cloning: A Laboratory Manual (Cold Spring Harbour Labarotory Press, Cold Spring Harbor, NY, USA, 1989).

40 Marengo-Rowe, A. J. Rapid electrophoresis and quantitation of haemoglobins on cellulose acetate. J. Clin. Pathol. 18, 790-792 (1965).

41 Vella, F. Acid-agar gel electrophoresis of human hemoglobins. Am. J. Clin. Pathol. 49, 440-442 (1968)
42 Saiki, R. K., Scharf, S., Faloona, F., Mullis, K.B., Horn, G. T., Erlich, H. A. et al. Enzymatic amplification of beta-globin genomic sequences and restriction site analysis for diagnosis of sickle cell anemia. Science 230, 1350-1354 (1985).

43 Sutton, M., Bouhassira, E. E. \& Nagel, R. L. Polymerase chain reaction amplification applied to the determination of beta-like globin gene cluster haplotypes. Am. J. Hematol. 32, 66-69 (1989).

44 Mihara, M. \& Uchiyama, M. Determination of malonaldehyde precursor in tissues by thiobarbituric acid test. Anal. Biochem. 86, 271-278 (1978).

45 Shimauti, E. L., Silva, D. G., Almeida, E. A., Zamaro, P. J., Belini-Junior, E. \& Bonini-Domingos, C. R. Serum melatonin level and oxidative stress in sickle cell anemia. Blood Cells. Mol. Dis. 45, 297-301 (2010).

46 Veith, R., Galanello, R., Papayannopoulou, T. \& Stamatoyannopoulos, G. Stimulation of F-cell production in patients with sickle-cell anemia treated with cytarabine or hydroxyurea. N. Engl. J. Med. 313, 1571-1575 (1985).

47 Poillon, W. N., Kim, B. C., Rodgers, G. P., Noguchi, C. T. \& Schechter, A. N. Sparing effect of hemoglobin $\mathrm{F}$ and hemoglobin A2 on the polymerization of hemoglobin $\mathrm{S}$ at physiologic ligand saturations. Proc. Natl Acad. Sci. USA 90, 5039-5043 (1993).

48 Steinberg, M. H., Lu, Z. H., Barton, F. B., Terrin, M. L., Charache, S., Dover, G. J. et al. Fetal hemoglobin in sickle cell anemia: determinants of response to hydroxyurea. Multicenter study of hydroxyurea. Blood 89, 1078-1088 (1997).

49 Wood, K. C. \& Granger, D. N. Sickle cell disease: Role of reactive oxygen and nitrogen metabolites. Clin. Exp. Pharmacol. Physiol. 34, 926-932 (2007).

50 Balla, J., Vercellotti, G. M., Jeney, V., Yachie, A., Varga, Z., Jacob, H. S. et al. Heme, heme oxygenase, and ferritin: how the vascular endothelium survives (and dies) in an iron-rich environment. Antioxid. Redox Signal. 9, 2119-2137 (2007).

51 Marchand, A., Galen, R. S. \& Van Lente, F. The predictive value of serum haptoglobin in hemolytic disease. JAMA 243, 1909-1911 (1980).

52 Bourantas, K. L., Dalekos, G. N., Hakis, A., Chaidos, A., Tsiara, S. \& Havridis, A. Acute phase proteins and interleukins in steady state sickle cell disease. Eur. J. Haematol. 61, 49-54 (1998).

53 Dhaliwal, G., Cornett, P. A. \& Tierney, L. M. Jr Hemolytic anemia. Am. Fam. Physician 69, 2599-2606 (2004)

54 Kupesiz, A., Celmeli, G., Dogan, S., Antmen, B. \& Aslan, M. The effect of hemolysis on plasma oxidation and nitration in patients with sickle cell disease. Free Radic. Res. 46, 883-890 (2012).

55 Nur, E., Biemond, B. J., Otten, H. M., Brandjes, D. P. \& Schnog, J. J. CURAMA Study Group Oxidative stress in sickle cell disease; pathophysiology and potential implications for disease management. Am. J. Hematol. 86, 484-489 (2011)

56 Steinberg, M. H. Predicting clinical severity in sickle cell anaemia. Br. J. Haematol. 129, 465-481 (2005)

57 Moreira, J. A., Laurentino, M. R., Machado, R. P., Barbosa, M. C., Gonçalves, R. P., Mota, A. M. et al. Pattern of hemolysis parameters and association with fetal hemoglobin in sickle cell anemia patients in steady state. Rev. Bras. Hematol. Hemoter. 37, 167-171 (2015).

58 Belini-Junior, E., Silva, D. G., Torres, L. S., Almeida, E. A., Cançado, R. D., Chiattone, C. et al. Oxidative stress and antioxidant capacity in sickle cell anaemia patients receiving different treatments and medications for different periods of time. Ann. Hematol. 91, 479-489 (2012).

59 Torres L. S., Silva, D. G., Belini-Junior, E., Almeida, E. A., Lobo, C. L., Cançado, R. D. et al. The influence of hydroxyurea on oxidative stress in sickle cell anemia. Rev. Bras. Hematol. Hemoter. 34, 421-425 (2012).

60 Silva, D. G., Belini-Junior, E., Torres L, S., Ricci-Junior, O., Lobo C. C., BoniniDomingos, C. R. et al. Relationship between oxidative stress, glutathione S-transferase polymorphisms and hydroxyurea treatment in sickle cell anemia. Blood Cells Mol. Dis. 47, 23-28 (2011) 